\title{
Image Redesign as a Tool for Safeguarding a Destination's Market Prosperity: The Case of Dubrovnik
}

\author{
Ivo Kunst \\ Institute for Tourism, Zagreb, Croatia \\ e-mail: ivo.kunst@iztzg.hr
}

\begin{abstract}
The city of Dubrovnik, particularly its historical core protected by UNESCO and the space in its immediate vicinity, has been exposed to an excessively growing tourist demand for more than a decade. This is especially true in the case of one-day transit visitors originating either from cruise ships or from organized tourist groups. As a consequence, the historic city centre is experiencing growing tourist congestion. This is accompanied by a constant decrease in the quality and structure of food and beverage and other tourism related services, which are adapting themselves increasingly to a less demanding transient tourism demand. The above developments not only severely undermine the local population's quality of life, but also have important implications for the long-term image of Dubrovnik on the tourism destinations market. Following a critical examination of Dubrovnik's prevailing tourism development policy and its viability, not only from its socio-economic perspective, but in the context of its long-term impact on the city's market prosperity as well, this paper, based on qualitative research insight, proposes changes in the City's unique selling proposition in order to decrease the problem of tourist congestion and sustain Dubrovnik's competitiveness on the tourism destination market in the years to come.
\end{abstract}

Key words: Dubrovnik, tourism development model, market prosperity, sustainability.

\section{Introduction}

Due predominantly to the quality (uniqueness and authenticity) of its cultural heritage, the city of Dubrovnik, particularly its historical core protected by UNESCO, has for a number of years been exposed to growing tourist demand. As a result, Dubrovnik is today arguably not only the internationally most recognizable tourist destination in Croatia, but one of the several 'must see' Mediterranean destinations as well. Compared to other Croatian tourist destinations, Dubrovnik is characterized by: (i) the highest share of high class hotels $\left(5^{*}\right)$ in the structure of the hotel offer, (ii) the highest share of hotel accommodation in total accommodation offer, (iii) 
the highest hotel occupancy rates, (iv) the lowest level of seasonal fluctuations in demand, (v) the highest level of average spending per day of tourist stay, and (vi) the greatest interest for visitation from cruise-ship companies.

Apart from the steady growth of stationary guests, the growing tourist demand for Dubrovnik refers especially to one-day transient visitors originating either from cruise ships, or from organized tourist groups. As a result of this process, the historic city centre has, for many years now, been exposed to a growing number of simultaneous visitors. Increasing tourist interest for the historic city centre, coupled with a steady rise in real-estate prices, initiated the process of ubiquitous gentrification of the city centre. The city centre gentrification process is, on the other side, accompanied by a constant decrease in availability of public infrastructure, as well as by declining quality and changing structure of food and beverage and other tourism related services, which are adapting themselves increasingly to a less demanding transient tourism demand. The above developments have important implications not only for the city's 'spirit of place', but also for the long-term market prosperity of Dubrovnik and its image on the tourism destinations market. Namely, the continuation of the present development trends could result not only in a complete 'touristification' of both, the public and private spaces within the historical city centre including, in part, the adjacent areas as well, but also in the rampant 'musealization' of the most attractive part of the City. In such conditions, it will become ever more difficult to maintain genuine image of Dubrovnik on the global tourism market.

Based on the relevant determinants of a destination's image creation (Morgan, Pritchard and Pride, 2004; Anholt, 2007; Anholt, 2009), destination competitiveness (Ritchie and Crouch, 1999; Ritchie and Crouch, 2003), rules of the experience economy (Pine and Gilmore, 1998), and differentiation as a means for gaining a competitive advantage (Porter, 1980), this paper aims to: (i) critically re-evaluate the viability of the existing tourism development policy, particularly in the context of its long-term impact on the image of the City as a global and mega-popular tourist destination; and (ii) indicate the direction for the necessary changes in the long-term positioning of the City that should prevent the destruction of its brand identity and reinforce its value on the tourism market.

\section{Literature review}

Since a tourist destination represents a clearly delineated geographic area which can be actively managed and in which a large number of co-producing actors offer a variety of tourist experiences (Buhalis, 2000; Haugland et al, 2011; Morisson, 2013), the competitiveness of a tourist destination can be defined as "the ability to increase tourism expenditure, to increasingly attract visitors while providing them with satisfying, memorable experiences and to do so in a profitable way, while enhancing the well-being of destination residents and preserving the natural capital of the destination for future generations" (Ritchie and Crouch, 2000). 
Under the influence of growing tourist demand on the global level, which is expected to remain stable in the long run (UNWTO, 2016), the proliferation of an increasing number of attractive tourist destinations across the world, and the ever greater segmentation of tourist interests (Gonzales and Bello, 2002; Trauer, 2007), the tourist market is characterised more and more by a growing struggle to ensure the interest/affinity of (pre)defined (targeted) demand segments. In that sense, the destination tourism policy must, more than ever, focus on a permanent improvement of its own competitive capability (Dwyer at al, 2009). That is achievable only if a suitable institutional framework is established, capable to monitor, control and increase the product quality of different tourism related entrepreneurs on one side, as well as to protect the resource basis of the destination on the other (Goeldner, Ritchie and McIntosh, 2000).

Although there is a high level of compatibility in the attitudes of the leading tourism experts in terms of the elements that influence the competitiveness of tourist destinations, mainly as a result of well-defined theoretical models (Hassan, 2000; Ritchie and Crouch, 2003; Dwyer and Kim, 2003; Heath, 2003), when examining the issue of the competitiveness of tourist destinations, it is more important to understand the sources of destination's competitiveness than its intensity (Kunst, 2009).

Long-term sustainability of the market position of a tourist destination on the global market stems predominantly from the created quality perception of the available tourist experiences as well as from the associated consumer benefits, compared to all the other tourist destinations (Kunst, 2009). The fundamental prerequisite for a competitively efficient, and thus sustainable destination positioning in the long term is to provide a system of unique and authentic travel experiences attractive enough to potential visitors so that they will choose one particular destination, and not any other. While the tangible (hotel room, food and drinks, the number of cultural monuments and the like), and intangible aspects (atmosphere, mood, ambient etc.) of the tourist experience are equally significant components of the destination product, tangible aspects of the tourist experience are those that are, in fact, sold/ bought. Nevertheless, the intangible aspects of a destination product constitute the essence that is particularly highlighted in advertising campaigns as unique and unforgettable. It can, therefore, be concluded that the basic determinant of long-term sustainable competitiveness of any tourist destination represents mostly its ability to efficiently differentiate itself from the potential competition by offering a larger or smaller number of tourist experiences that are difficult (or impossible) to imitate (Pine and Gilmore, 1999).

Apart from the (objectively determined) consumer benefits, the long term success of any tourist destination in sustainably attracting the steady flow of tourists largely depends on its globally perceived image on the tourism destination market (MacKay and Fesenmaier, 1997; Pike, 2002). In fact, destination image and destination brand recognition represent nowadays key factors in the process of destination selection for potential tourists (Morgan, Pritchard and Pride, 2004; Tasci and Gartner, 2007; Baloglu and Brinberg, 1997; Chen and Tsai, 2007) since the tourists, in most cases, are unaware to what extent their perceived image coincides with the objective 
reality (Hunt, 1975; Gunn, 1988). This is one of the main reasons why the World Tourism Organization, nearly 40 years ago, declared the importance of a positive destination/country image (WTO, 1979).

Following Hunt's work, various authors have tried to define a destination's image and the factors that determine it. For instance, Lawson and Baud-Bovey (1977) define a destination's image as "the expression of all objective knowledge, impressions, prejudice, imaginations, and emotional thoughts an individual or group might have of a particular place". According to Crompton (1979), a destination's image is "the sum of beliefs, impressions, ideas and perceptions' that people hold of a place". Della Corte and Micera (2007) define destination image as "the whole of beliefs, ideas and impressions a destination can generate in potential and actual tourists' minds", whereas Hose and Wickens (2004) define destination image as any "visual, oral or written representation of a tourism location that is recorded and can also be transmitted to others". Dimanche (2003), on the other hand, is of the opinion that "the image of a destination is the sum of all perceptions tourists and potential visitors hold of that destination". He also highlights that the destination's image "evolves with time and events that are controlled, or not, by the destination". In this regard, it may be concluded that the formation of a destination's image depends on internal and external factors. In this regard, the destination's image is ever more intertwined with factors such as familiarity with a destination, previous visitation and various socio-demographic factors (Chaudhary, 2004; Beerly and Martin, 2004). Finally, Milman and Pizam (1995) suggest that a destination image consists of three components: the quality of the attraction base, attitudes of the destination hosts and their behaviour, as well as the supporting environment: weather, scenery, and facilities.

Regardless of similarities or dissimilarities in definitions, there seems to be a general understanding that destination image is a multi-faceted, composite construct, created from information gathered from numerous sources. Since it consists of interrelated cognitive and affective evaluations woven into an overall impression (Baloglu and McCleary, 1999; Beerly and Martin, 2004; Stepchenkova and Morrison, 2006), it is only logical to expect that diverse stakeholders should coordinate their efforts in order to come up with a joint definition of a destination's 'competitive identity' (Anholt, 2007).

\section{Setting the scene - status quo analysis}

Having in mind a well-documented positive correlation between destination image and the decision to visit it, it is particularly important to emphasize that superior destination image relies heavily on the attractiveness of the destination's cultural heritage (Palmer, 1999; McKercher, 2001; Richards, 2007). Emphasizing the uniqueness of its cultural heritage, even in the case of gradual standardization and 'commoditization' of the accommodation facilities and other catering offer, the destination is enabled to effectively generate heritage rent (Kunst, 2008) and secure itself a superior market position in the long term. 
In the case of Dubrovnik, all of the above is well-corroborated by the analysis of the synthetic success indicator of the hotel industry revenue generation in representative Croatian coastal destinations, defined as a product of the prices of hotel accommodation and gross bed occupancy rates (Figure 1).

Figure 1

Income generation capacities per potential unit of accommodation capacity of selected Croatian coastal destinations

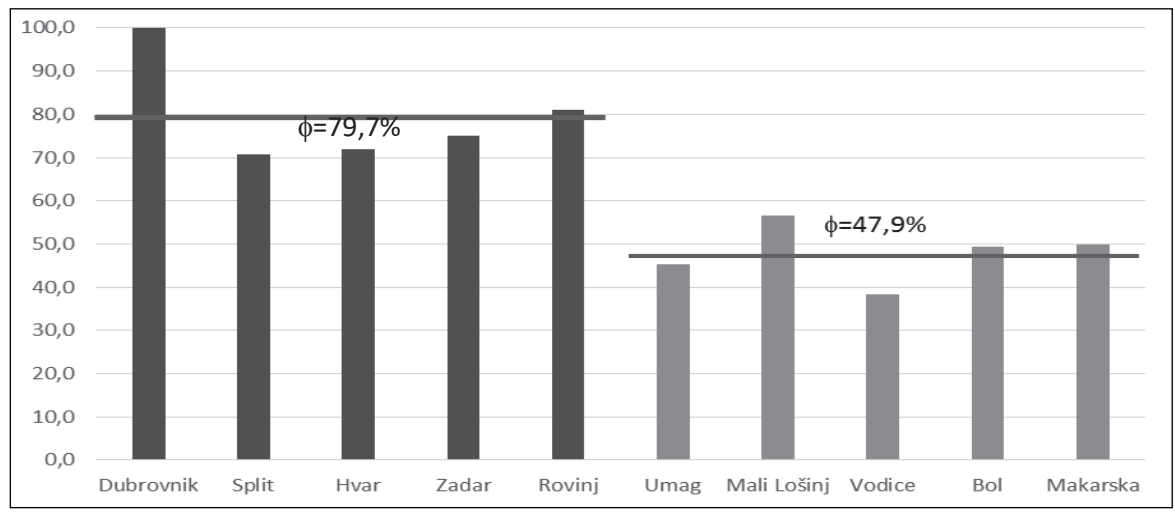

Source: hotel prices listed on www.booking.com (2014); number of overnight stays and accommodation capacity (2013) of hotels; Croatian Bureau of Statistics, analysis done by the author

Namely, among several Croatian tourist destinations that base their market positioning predominantly on the quality and uniqueness of their (material) cultural heritage, the hotels in Dubrovnik achieve by far the highest revenue per available bed. Furthermore, figure 1 shows explicitly that all Croatian tourist destinations that base their image and market positioning predominantly on the uniqueness of their cultural heritage, generate a significantly higher level of revenue per accommodation unit than those destinations which are unable to position themselves in the same way.

Apart from the constant increase in the performance of the hotel industry in Dubrovnik in the past decade, the rapidly rising tourist interest for Dubrovnik as a must see destination has a somewhat 'darker' side as well. Namely, under the prevailing neoliberal economic practices (Harvey, 2007), particularly in the context of globalisation, it seems that Dubrovnik's image as a tourist destination has been formed according to the needs of: (i) global tour operators, (ii) large hotel and cruise ship companies, and/or (iii) global investors. At the same time, the interests and needs of local stakeholders have been largely neglected. As a result, Dubrovnik's tourism image has been formed mostly in accordance with the concept of 'the tourist gaze' (Urry, 2001; Urry and Larsen, 2012). In other words, the image of Dubrovnik as it exists today has been reduced mostly to what the tourist industry considers to be the easiest to sell. Consequently, the domination of the 'tourism industry's' influence is most intensively manifested within the UNESCO protected historical city centre and the zones that gravitate towards it. If the existing trend prevails in the future, the long-term image of Dubrovnik on the tourist market will certainly be significantly af- 
fected, resulting in an unavoidable shift in the structure of tourist demand. Namely, the dynamic increase in demand for Dubrovnik as a tourist destination brings about an increasingly greater 'touristification' and commercialisation of the available public space, causing irretrievable damage in the city's cultural code ('genius loci') that has been created for centuries. In this regard, one should emphasize especially the following processes:

- Encouraged by a large demand for real estate and, consequently, their high prices, the autochthonous inhabitants of the historical City centre are rapidly selling their housing and/or commercial units to persons who stay in the City only on a temporary, occasional and short basis. With the accelerated gentrification of the historical city centre (and the adjacent area), results in a substantial reduction not only in the authenticity, but also in the emotional charge of the integral tourist experience (Pine and Gilmore, 1999).

- Further, the mere fact that a significant part of the housing stock within the historical city centre is not in use for a large part of the year has an unfavourable additional affect not only the vitality of the UNESCO protected core, but also on the prevalent use of the public space within it. In this regard, there are scarcely any business/service premises in the historical city centre that predominantly serve the needs of the local population (i.e. grocery shops, public utilities, post offices, infirmaries, kindergartens etc.).

- Since the crowds caused by an increasing number of simultaneous visitors in the historical city centre, particularly as a result of the growing number of oneday visitors (cruise ships, organised groups of holidaymakers), are getting larger year after year, most of Dubrovnik's citizens try to avoid coming to the historical city centre as much as possible, especially during the prolonged tourist season. As a result, for a large part of the year, the historical city centre is 'liberated' from the presence of the local population. One can, therefore, rightfully talk of its increasing 'musealization' (Mišetić and Miletić, 2014), where the historic city centre is being ever more used only as an extremely attractive visual backdrop intended for a one-time only use by the increasing number of (one-day) visitors.

- The use of the public space, particularly within the historical city centre and its immediate vicinity, is increasingly being adapted exclusively so as to serve the needs of one-day/single excursionist demand. The consequence thereof is an increasing typification, commodification and 'internationalisation' of the catering and any other tourist related service. This results in a constantly diminishing level in the service quality as well as in the evident absence of local flavour and authenticity in the offer.

Having in mind these less positive aspects of Dubrovnik's popularity growth among tourists and one day visitors, one can rightfully raise the issue of long term sustainability of the City's positive image on the tourism destination market. As a consequence, and particularly in regard to the possible further changes in the structure of the demand and the level of average tourist spending, this would have a negative impact on the business results of both, individual, tourism related, entrepreneurs, and the entire destination (Telišman Košuta, 1994; Beerli and Martin, 2004). 


\section{Methodology}

In order to gain more insight into the social and economic implications of the ever more prevalent growth of the one-day (excursion) demand within the historical centre of Dubrovnik and its immediate vicinity, as well as the consequences of the 'touristification' of most of the predominantly public areas within the City walls on the sustainability of Dubrovnik's global image as a 'must see' destination, primary data were collected by means of a stakeholder consultation process. The key argument for such a methodological approach lies in the presumption that the desirable future vision of Dubrovnik as a mega-popular tourist destination can be translated into reality only if the dominant stakeholders share similar attitudes on how the future should look like (Butler, 1980; Getz, 1992; Simpson, 2001; Wehrmeyer, Clayton and Lum, 2002; Reid, Mair, and George, 2004; Butler, 2009; Van der Helm, 2009).

The stakeholder consultation process was conducted through a semi-structured interviews with selected representatives of different stakeholder groups, all with good understanding not only of the Dubrovnik's tourism development model, but of its potential, direct and/or indirect socio-economic, spatial, ecological and/or cultural side-effects as well. Each of the persons to be interviewed was contacted by the author in advance in order to secure their cooperation, and to inform them in greater detail about the topics to be discussed. Further, in order to give them proper time to prepare, a prepared questionnaire was sent to each of the respondents a few days before the date of the interview. The interviewed persons included: (i) local politicians (5), (ii) hotel, restaurant and travel agency owners (6), (iii) prominent participants of the Dubrovnik's culture scene (5), (iv) representatives of Dubrovnik's educational institutions (3), as well as (v) representatives of the NGOs and/or relevant civic organisations promoting 'green' development practices (4). Altogether, a total of 23 persons have been interviewed. Individual interviews, lasting for 60-90 minutes, were all held in Dubrovnik. The entire research was conducted in May 2014.

Individuals to be interviewed were selected via the snowball sampling method, an approach originally developed by Goodman (1961), which is quite often used in tourism related research (i.e. Stylianou-Lambert, 2011; McLennan, Ritchie, Ruhanen, Moyle, 2014). Following the snowball sampling method approach, each preselected interviewee was asked to indicate a list of other prospective contact persons, and then the process was repeated. Interview topics were deliberately presented in as neutral a way as possible so as to invite interviewees to interpret issues in a way they considered most appropriate.

The interviewees answered questions grouped into four sets of interrelated topics of interest, covering: (i) the role of tourism and its significance for the City, (ii) the factors that have mostly contributed to Dubrovnik's image and its global recognition as a 'must see' destination, (iii) the challenges for Dubrovnik's tourist development in the future, and (iv) the aspects of Dubrovnik's desirable (tourism) development. 


\section{Results and discussion}

\section{The significance of tourism for the City of Dubrovnik}

Tourism is considered to be the most important economic activity in Dubrovnik on which the City is now almost completely dependent. The attitude that '... Dubrovnik lives off tourism' is unanimous.

Apart from fact that tourism has unanimously been recognised as 'the main driving force' for the City's economy, and according to some even 'an activity without which the City could no longer exist', the respondents also expressed a certain disquietude since tourism tends to 'suffocate' other economic activities that characterized Dubrovnik's economy in the past (i.e. seafaring, crafts, industrial production and/or agriculture), thus growing into a monoculture. Moreover, judging by the attitudes of some of the respondents, summarised in comment such as if you have no affinity for foreign languages, hospitality or apartment rental, you have no business living in Dubrovnik ...', the tourism industry within the City is being characterized by an increasing focus on the rudimentary and very simplified tourist offer reduced to the basic aspects of the tourist product.

Further, as another alarming consequence of over-reliance on tourism, some of the respondents indicated the increase of the 'spirit of rent-seeking' that diminishes the values of higher education ('.. they expect to live from renting apartments ...'), and labour ('... they work for half a year, and spend the other half idly ...'), which leads to the paradoxical phenomenon of individuals getting richer and the local community getting poorer.

\section{Determinants of the 'Dubrovnik image'}

Dubrovnik is indisputably considered to be a globally recognisable destination. The proof for this statement lies in the fact that '.. it is never necessary to explain what Dubrovnik is and where it is located, ...that Dubrovnik regularly appears in the global media as a 'must-see' tourist destination, ...that a large number of foreign tour-operators include the City as an essential part of their offer ...' According to some respondents, Dubrovnik is at the same time more recognisable on the tourist market than Croatia itself.

Furthermore, the respondents agree that the Dubrovnik image on the tourist market should be connected mostly with its exceptional cultural/historical heritage, particularly with the UNESCO protected city centre surrounded by the walls. The image of a preserved medieval city ' $\ldots$ as a unique urban composition ... organised according to humane criteria ... with a complex offer of diverse public and residential buildings, rich history, famous individuals, events and experiences ... ' represents the core of Dubrovnik's unique selling proposition. This is expressed in the attitude 
'... frankly speaking, tourists come to see the old historical centre. It generates recognition and represents a magnet on which everything else builds. In that sense, it is not surprising that most of the respondents believe that the clear sea, cultivated landscape, mild climate, local gastronomy, folklore or other heritage elements of intangible character are perceived by the market primarily as 'accompanying features' of lesser importance. The old historical core is, therefore, not only the main factor of market differentiation, but also the core of the tourist attractiveness of Dubrovnik.

To conclude, apart from recognising the iconic status of the historical centre, the research also indicated the fact that tourism in Dubrovnik is concentrated in an extremely small and increasingly more saturated space, while, at the same time, a more adequate (tourist) valorisation of the other city areas and/or the distinctive local features are systematically overlooked. In that context, and since the life of local population is seriously undermined by tourism development, according to most of the respondents, the tourist development of Dubrovnik is 'difficult to sustain in the longer term'. This makes the management of tourism development in the City increasingly more challenging. The same is true for the City's image as well.

\section{Challenges for Dubrovnik's tourism development in the future}

Notwithstanding the relatively positive perception of their stay in the City by tourists (Tourist Association of Dubrovnik, 2013; Marušić, Čorak and Sever, 2015), and taking into account the established position and the quality of its resource and attraction basis, most of the respondents believe that Dubrovnik should and could do better. Noting that Dubrovnik is by far ahead of other Croatian tourist destinations not only due to its concentration of high-category hotels, but also due to its hotel occupancy rates, the amount of tourist expenditure per day, the guest structure (dominated by tourists from distant European countries, and the overseas markets), as well as due to the duration of its season, all of the respondents agreed that the existing market position should not only be maintained, but additionally improved with continuous and coordinated activities of stakeholders from both, the public and private sectors. Most of the respondents further agreed that there are several important weak points and/or imbalances that already distort the image of the City on the tourist destination market.

Firstly, for some years now there has been a trend of the uncontrolled exposure of the City, particularly its historical centre, to the high and ever-increasing pressure from market segments that stay in Dubrovnik only a short period of time. This demand, in particular, consists not only from cruise ships visitors that typically reside in the city for just a few hours, but from visitors from the surrounding tourist destinations who come for a day trip, as well as from visitors on organized tours which typically stay for a day or two. In contrast to stationary guests, the increasingly more popular transient demand gradually transforms Dubrovnik into a destination mainly for excursionists. As a consequence, according to the respondents, 'the character of the tourist offer in the City has changed dramatically, i.e. it has been reduced to only cafés and restaurants with faster and faster food, two types of souvenir shops - those selling plastic 
kitsch and those with slightly more expensive original Croatian products in stock, and an enormous number of taxis'. Furthermore, in order to fulfil that kind of visitor's needs results in an ever growing need for new catering space. This, according to most of the respondents, brings about the fact that 'cheap restaurants are taking over the streets, usurping the public space, which is being commercialised and privatised for the needs of enterprising individuals'. It is believed, finally, that the increasing number of guests who stay in Dubrovnik only for a short period of time seriously undermine the quality of the integral service due mostly to the lack of quality certification, as well as to the non-existing service quality assurance. Since the prices, on the other hand, remain extremely high, one can only expect a systematic degradation of not only the quality of experience for all guests who come to Dubrovnik, but also a gradual degradation of the image of the City on the tourist destination market. Accordingly, one should be aware of the risk that 'Dubrovnik might gradually convert into a oneday 'must-see' destination where guests will be willing to patiently endure crowds and unreasonable prices, whereby after the initial visit, will never come back again'.

The second weak point highlighted by the respondents concerns the rapid gentrification of the part of the City which is the most attractive to tourists - the historical centre. While some respondents claim that it is an unavoidable process whereby, by and large, the poorer population of the historical city centre have been overcoming their financial problems, the majority of respondents share the opinion that 'the old city centre is turning into a mere backdrop', 'a stage for strolling about', and that 'the visitation experience of the Old Town is being increasingly profaned' as a result of growing 'typification/unification of the service offer'. Finally, some respondents pointed out that 'the backdrop effect is more or less economically justified through rent collection, but since there are no more native citizens, the recognisable 'spirit of the city' is gone for good'. The only local people that can be nowadays seen in the historical city centre are waiters.

Third neuralgic point of interest for the tourist development of Dubrovnik and its image on the tourist destination market to which the respondents specifically indicated, refers to the growing disparity between the tidiness of the historic centre and other, particularly fringe, parts of the City. In addition, the respondents pointed out the difference in the quality of the communal services, as well as the evident decline in 'green' areas. Most of the respondents also share the opinion that the development of the transport and utility infrastructure is unable to match the development of the urban fabric ('the congestion in the city during the high season is unbearable'... 'there are no sewers in the City, ... during the high season the electric energy supply is insufficient etc.').

Finally, since the contrasting harmony of the 'sea, historical city centre and steep slopes of Mt Srd' is, by all the respondents, considered to be one of the trademarks of Dubrovnik's visual and socio-cultural identity, there is no doubt that this 'visual unity' should be preserved at any cost. As a result, most of the respondents consider the construction in that area, be it for the purpose of expanding the housing stock, construction of tourist facilities, or establishment of recreational areas (such as golf), a potential threat that should be treated with extreme care and sense of proportion. 
Summarizing the prevailing respondents' attitudes, it seems that the stakeholders are aware that the existing tourism development model in Dubrovnik, despite the ever increasing number of tourist arrivals and/or business generated by the private sector, has a negative impact not only on the quality of visitation experience, but on the quality of living as well. Accordingly, most of the respondents lean towards 'balancing' the dynamics of tourism development and the wellbeing of local population. This calls for a more appropriate use of the cultural (and natural) heritage in a way that would ensure a better quality of life for the local population not only in the financial, but also in the socio-cultural sense. It is therefore only natural that most of the respondents raised the question of the suitable way forward?

\section{Aspects of desirable (tourist) development of Dubrovnik}

With regard to the future tourism development of Dubrovnik, the respondents overwhelmingly emphasized the need to replace the current 'spontaneous' and 'haphazard' short-term approach to tourism development with a strategic long-term approach that would carefully consider how to preserve all vital resources of the City. This is reflected in the attitudes such as '...planning beyond a period of four years is required, ... one should take account of the space and resource availability, ... goals should be set that are acceptable to citizens, ...professional identification of the limitations to development is necessary'. The long term protection of natural and cultural resources is considered to be a priority according to which the extent of future tourism development should be determined. This involves 'the establishment of a system which lays down in advance the requirements that investors have to abide to without exception'. Similarly, the prevalent attitude is that the City should strive to 'attract more guests who tend to stay longer, who visit Dubrovnik throughout the year, and who would appreciate the affluence of diversity'. Nevertheless, most of the interviewees are not against cruise ship visitation and share the opinion that Dubrovnik should remain a cruising destination. However, they indicate 'that the whole cruise ship business should in the future be better controlled than is the case today.' The issue of cruise ship business control, however, does not imply only the introduction of restrictions aiming to facilitate/optimize tourist movement in the old city centre. In this regard, therefore, it is simply necessary to cut the number of cruise ship arrivals per day, increase the tariffs that would destimulate the number of port calls, and target lower-capacity ships'. In any case, 'one should respect the UNESCO suggested maximum of no more than 7,000 daily visitors within the old city centre'.

Finally, with the attitude that 'tourism in Dubrovnik has to reflect the right measure and harmony', a certain number of interviewees believes that this goal can be achieved mostly through a gradual dispersion of tourist interest away from Dubrovnik itself. This can be done by linking the 'Dubrovnik brand' with the entire area of the former Dubrovnik Republic. The idea of 'Dubrovnik being a nucleus, and its periphery the perfect location for the placement of new tourist offer facilities' should lead to a significant relief in the touristification of public space in Dubrovnik, both in terms of its number of concurrent users, and in terms of the possible new construction. The inner centre of the City would, thus, to a large extent be 'liber- 
ated from the crowds created by an excessive number of tourists/visitors', and, thus, more available to the local population and their needs. This includes 'the provision of space for various public and cultural events' which is being marginalised by today's concept of tourism development. In addition, the expansion of the Dubrovnik brand to a wider gravitating area would allow for 'the development of an autochthonous and thematic, less exclusive accommodation offer', and create 'an additional stimulus for the development of new tourist experiences for which there is simply no space within the City itself. In this regard the interviewees mentioned especially golf courses, wine/gourmet tourism establishments, as well as activity based tourism infrastructure as main attractors for new potential customers'. All this would additionally enrich and diversify today's tourist offer of the City and its vicinity.

\section{How to sustain Dubrovnik's market prosperity?}

Regardless of its globally imposed image created predominantly in line with what the tourist industry imposes as necessary, and resulting in the recognition of only a few of 'standard' cityscapes of the historical city centre, it seems that Dubrovnik's image on the global tourism market should be much more layered and complex. This calls for the inclusion of additional cognitive and affective elements that would not only enrich the City's rather shallow and superficial market identity, but whose interplay would allow for various interrelations that would bring about a different emotional flavour to the whole destination (Hosany, Ekinci and Uysal, 2007; Keller, 2008).

Taking into consideration the interviewees' opinions on the Dubrovnik's most relevant image determinants, apart from the omnipresent historical city centre and its photogenicity, the factors that seem to be of great significance not only to the local population, but to the cultural/historical community as well, include: (i) the historical and civilizational inheritance of the Dubrovnik Republic, (ii) globally relevant historical personalities such as Marin Držić, Ivan Gundulić, Ruđer Bošković, Marin Getaldić or Vlaho Bukovac, (iii) individual secular and/or sacral buildings of great beauty and/or cultural significance at the edge of the City or around it (villae rusticae, medieval fortifications, monasteries and sacral buildings), (iv) numerous cultural events and/or international 'festivities' related to Dubrovnik's intangible heritage, (v) cultivated landscape (particularly at the 'edge' of the City), as well as the (vi) mild climate, (vii) beauty of the nature, (viii) abundance of tourist related superstructure, and (ix) autochthonous eno-gastronomic offer of great quality. All these elements should, therefore, become integral parts of the overall Dubrovnik image, and, hence, be included in the overall visitation experience.

However, due to differences in their relative importance, it seems logical to differentiate between the elements that form: (i) the core of Dubrovnik's identity, (ii) its expanded identity, and (iii) its supplementary identity. The elements forming the core of Dubrovnik's identity should be most relevant in emphasizing the City's uniqueness and authenticity. In other words, the core of its identity should represent Dubrovnik's unique selling proposition and act as the main differentiation factor. 
The expanded and supplementary identity elements, although less important as primary visitor attractors, also represent important image determinants and indicate that Dubrovnik is much more than just its UNESCO-protected historical city centre. With this in mind, the expanded and supplementary identity elements further extend and reinforce the core positioning statement.

In accordance with the answers provided by the respondents, it was possible to organize Dubrovnik's identity attributes as shown in Picture 2.

Figure 2

Layers of the Dubrovnik's identity and their elements

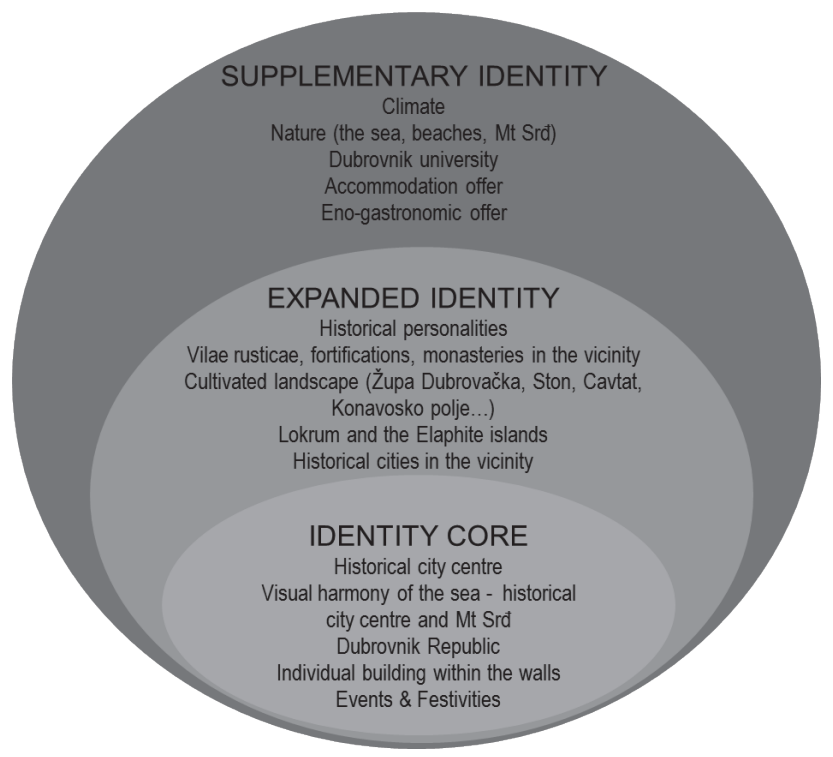

Source: Author, based on the interviewees' opinions and following the approach developed in Tomljenović and Kunst (2014)

Any violation of the factors determining the topography of Dubrovnik's identity, especially related to any inappropriate construction and/or inadequate use of public space, would automatically reflect itself as well on the Dubrovnik image to a greater or lesser extent, and would (negatively) affect the City's long-term market prosperity. Naturally, the potentially biggest threat to Dubrovnik's market prosperity is related to the degradation of the factors that represent the core of its identity. Since the most evident threat to the core of Dubrovnik's identity is reflected mostly by the usurpation of public areas, as well as by the gradual disappearance of the 'spirit of place' of the City's historic centre', it seems that the long term sustainability of the Dubrovnik brand on the tourism destination market calls for a gradual reduction in the number of simultaneous visitors within the city walls.

In order to effectively reduce the number of simultaneous visitors in the City's historic centre, one should not only reinforce all the vital determinants of the City's 
core, extended and supplementary identities, but also extend the general image of Dubrovnik and its unique selling proposition across the wider gravitating area of the former Dubrovnik Republic, an area that, not only for historical and cultural reasons, deserves to be an integral part of the overall Dubrovnik visitation experience. Figure 3 depicts the essence of the suggested approach as well as the logic for the gradual extension of the Dubrovnik brand to the gravitating area.

Figure 3

Dubrovnik's new market communication model

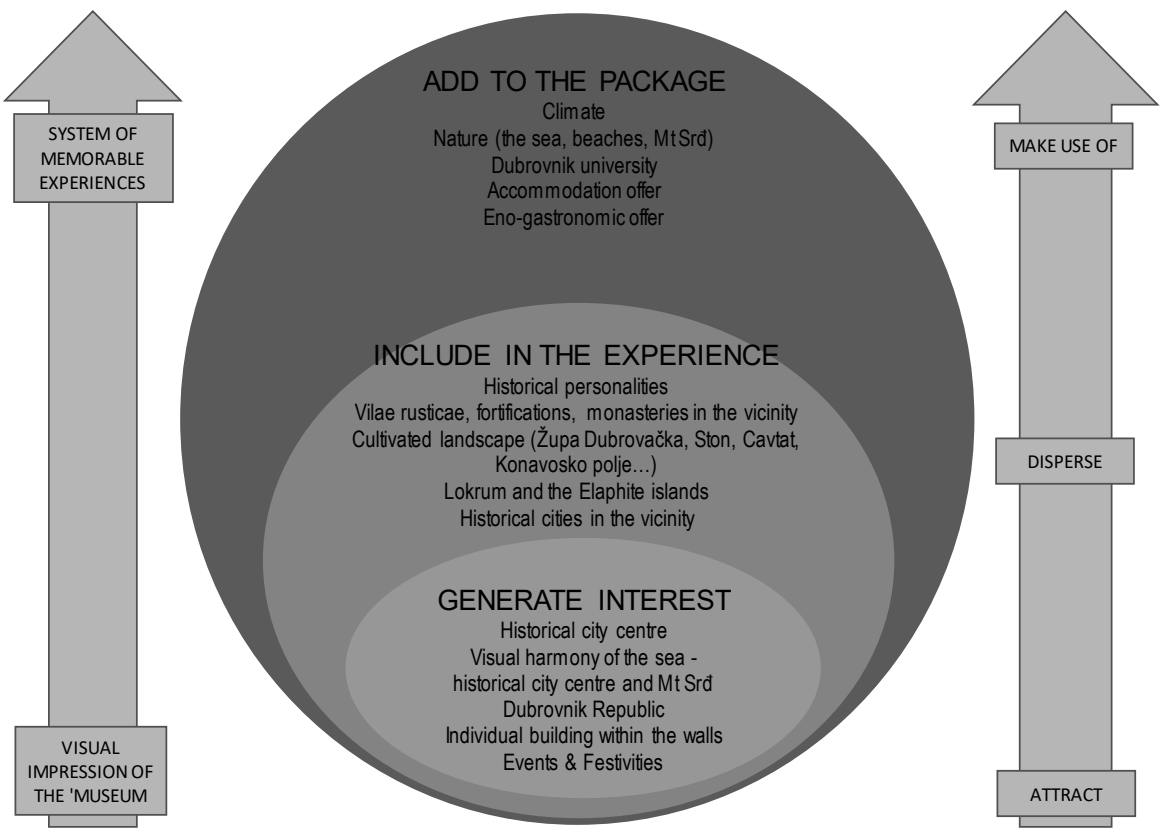

Source: Author, based on the approach developed in Tomljenović and Kunst (2014)

The central part shows the hierarchy of Dubrovnik's identity system and its determinants that need to be gradually, but efficiently, integrated into a complete system of memorable visitation experiences. In order to do so, the following logic in product commercialization is required: (i) use the iconic power and the visual appeal of the historical city centre as a primary attractor of various tourist demand segments, (ii) disperse the initially attracted demand in accordance with their prevailing interests and/or affinities to the (historical) 'periphery' of the City, and, finally (iii) complete the entire visitation experience by means of enjoyment in exceptional beauty of the nature, favourable climate, the quality of accommodation and/or high quality of the authentic eno-gastronomic offer.

Apart from the creation of preconditions for a better and socio-culturally more favourable usage of scarce space within the City walls and in order to ensure a more productive coexistence of tourists and local population during the prolonged season, the proposed approach to Dubrovnik's desirable market positioning should not 
only partially relieve the historical city centre from the crowds created by one-day visitors, but also add a new dimension to the still superficial (primarily visual) tourist impression of Dubrovnik, primarily of a petrified stone build 'museum city'. Further, the proposed approach would also enable a faster, and more efficient market recognition of new, mostly still unknown/undiscovered tourism experiences available in the City's 'periphery'. Finally, by means of getting more acquainted with the local culture and traditional way of life of the Dubrovnik's 'periphery', the suggested approach to Dubrovnik's market positioning should significantly extend the average length of stay, and create a foundation for a deeper and better structured visitation experience of Dubrovnik, allowing for a better understanding of its history, its culture (tangible and intangible), and its contribution to universal cultural heritage.

\section{Conclusion}

The rapid and intensive, sometimes even invasive development of tourism in the past decade has had a direct and indirect impact on the change of Dubrovnik's economic structure in which tourism has increasingly become a monoculture. At the same time, the spontaneous and sometimes haphazard development of tourism has also significantly affected the prevailing way of life in the City, especially with regard to: (i) the population's attitudes towards tourists/visitors, (ii) prevailing space use regime - particularly in the historical city centre - as well as to (iii) the availability/ effectiveness of the vital communal infrastructure systems. Although Dubrovnik has, so far, been able to successfully maintain itself on the global tourist destination market as a 'must see' destination, the present model of tourism development is being characterized predominantly by its propensity to increase profit, to the detriment of the preservation of cultural/natural heritage, visitor's experience, and the quality of everyday life for Dubrovnik's inhabitants. Despite the attempts to sensibly channel a part of the City's increased tourism receipts into the sphere of public goods, the existing development model cannot put an end to a series of problems related to communal infrastructure, rapid consumption space, profanation and degradation of green areas and/or unique cultural landscape. Therefore, not only the sustainability of the City's image, but its long term competitiveness are both at stake.

Regardless of the threats described above, it would be biased as well as unscientific to conclude that Dubrovnik will gradually attract a decreasing number of visitors and generate less tourism related receipts if the current trends continue to prevail in the future. The elasticity of demand suggests that it is reasonable to expect that 'every product usually finds its customer'. In this regard, one may argue that a reduction in the quality of an overall visitation experience and, thus, average spending, can be more than compensated by the increase in the number of arrivals and overnight stays. Such an argument is effectively supported by tourism development models of some other historical cities in the Mediterranean (i.e. Split, Kotor, Rhodes, Syracuse, Valletta, Ibiza), which, despite their excessive 'touristification' and/or 'musealization', are still considered to be very attractive tourist destinations that, albeit some less favourable socio-cultural and/or ecological consequences, still generate more than satisfactory tourism receipts. 
To conclude, only the citizens of Dubrovnik, based on their life preferences and fundamental beliefs, are in the position to decide on the sustainability and/or desirability of the existing model of Dubrovnik's tourist development. Nonetheless, however, there should be no doubt it is possible to significantly improve it. This conclusion can be corroborated by the following facts:

- Today's image of Dubrovnik as a tourist destination reflects largely the fact that the globalised tourist industry is extremely powerful when it comes to the 'production' and dissemination of destination images and/or identities. In this regard, it is extremely important to move away the visitation experience from only a 'photographic' perception of the 'museum city' and to revitalise the authentic 'spirit of the place', especially within the historical city centre, by striving to enable a more harmonious interaction between tourists and residents.

- The standardised images of Dubrovnik reflect the expected ('instant') manner in which the tourist industry suggests potential visitors how they are supposed to experience and consume the City as a tourist product: during their visit to Dubrovnik, tourists are expected to visit historical city centre and the most popular spots/buildings within the walls and, only if the time and their physical fitness allow it, take a stroll atop the city walls. Everything else in the City and outside it is reduced to unimportant and/or optional.

- Only the area within the walls and the experience that it offers is considered to be 'authentic' and extremely valuable, whereas the entire area outside the walls, as well as the area that historically gravitates towards the City, is considered to be of almost no value and, hence, not important. Apart from 'pushing' the crowds to the historical city centre, one should arouse the interest for the wider area of the former Dubrovnik Republic as well. Activating Dubrovnik's 'periphery' for more intensive tourist visitation would not only allow for new product development, but would significantly improve the quality of the overall visitation experience, reinforce Dubrovnik's core identity and extend its brand equity on the tourism destination market over the long run.

Instead of trying to incorporate a romanticised identity of the historical city into a typified commodified package the global tourist industry can most easily sell, it seems that a more desirable, more socially responsible and more sustainable development of Dubrovnik calls for the extension of the short, shallow, and superficial visitation experience of the historic city centre towards the broader area that once used to be an integral part of the Dubrovnik Republic. In order to achieve this goal, one should primarily focus on safeguarding the historically inherited, as well as the contemporary determinants within all three components of the Dubrovnik's identity system. Only in such conditions will it be possible to effectively manage the 'Dubrovnik brand' over the long run, and to the satisfaction of tourists, local entrepreneurs, and the local population. Finally, only in such conditions will it be possible to recognise the emergence of potentially unwanted scenarios of the City's (tourism related) development, and to create the necessary preconditions for a gradual expansion of the Dubrovnik's brand equity form the historical city centre (nucleus) to the outskirts of the City, including the whole area of the former Dubrovnik Republic. 


\section{References}

1. Anholt, S. (2007). Competitive identity: The new brand management for nations, cities and regions. New York: Palgrave Macmillan.

2. Anholt, S. (2009). Why national image matters: Introductory essay, in: Handbook on Tourism Destination Branding (pp. ix-xvi). Madrid: UNWTO i Bruxelles: European Travel Commission.

3. Apostolakis, A. (2003). The Convergence Process in Heritage Tourism. Annals of Tourism Research, 30: 795-812

4. Baloglu. S., and Brinberg, D. (1997). Affective images of tourism destinations. Journal of Travel Research, 35 (4): 11-15.

5. Baloglu. S., and Mc Cleary, K. W. (1999). A model of destination image formation. Annals of Tourism Research, 35(4), 11-15

6. Beerli, A. and Martin, J. D. (2004). Tourists' characteristics and the percieved image of tourist destinations: a quanitative analysis - a case study of Lanzarote, Spain. Tourism Management, 25: 623-636.

7. Buhalis, D. (2000). Marketing the competitive destination of the future. Tourism Management, 21: 97-116.

8. Butler, R. W. (1980). The concept of the tourist area life-cycle of evolution: implications for management of resources. Canadian Geographer, 24 (1): 5-12.

9. Butler, R. W. (2009). Tourism destination development: Cycles and forces, myths and realities. Tourism Recreation Research, 34 (3): 247-254.

10. Cabrini, L. (2002). Cultural heritage and tourism development, presentation at International Conference on Heritage, New technologies and Local Development, Ghent, September 11-13.

11. Chaudary, M. (2000). India's image as a tourist destination - a perspective of foreign tourists. Tourism Management, 2 (3): 293-297.

12. Chen, C. F., and Tsai, D. (2007). How destination image and evaluative factors affect behavioural intentions? Tourism Management, 28(4): 1115-1122.

13. Crompton, J. L. (1979). An assessment of image of Mexico as a vacation destination and the influence of geographical location upon that image. Journal of travel research, 17 (4): 18-23.

14. Della Corte, V. and Micera, R. (2007). Destination image analysis and management: results of an empirical research on the case of Naples. In proceedings of the $6^{\text {th }}$ International congress: Marketing Trends, Paris, France.

15. Derrett, R. (2001). Special interest tourism: starting with the individual, in $\mathrm{N}$. Douglas; N. Douglas and R. Derret (Eds.). Special interest tourism. Brisbane: Wiley, pp. 1-28.

16. Dimanche, F. (2003). Destination image evaluation: Part I. Elcipse (on-line), 9/10. Available at: (http://www.moonshine.es/ECLIPSE).

17. Dwyer, L. and Kim, C. (2003). Destination Competitiveness: Determinants and Indicators. Current Issues in Tourism, 6 (5): 369-414.

18. Dwyer, L.; Edwards, D.; Mistilis, N.; Roman, C.; Scott, N. (2009). Destination and enterprise management for a tourism future. Tourism Management, 30: 63-74.

19. Getz, D. (1992). Tourism planning and destination lifecycle. Annals of Tourism Research 19 (4): 752-770. 
20. Goeldner, R.; Ritchie, J. and McIntosh, R. (2000). Tourism. Principles, Practices, Philosophies, $8^{\text {th }}$ edition. New York: John Wiley \& Sons.

21. Gonzales M. A. and Bello, L. (2002). The construct „lifecycle“ in market segmentation: The hehaviour of tourist consumers. European Journal of Marketing, 36 $(1 / 2): 51-85$.

22. Goodman, L. A. (1961). Snowball sampling. Annals of Mathematical Statistics, 32 (1): 148-170.

23. Gunn. C. A. (1988). Vacionscape: Designing tourist regions. $2^{\text {nd }}$ edition. New York: Van Nostrand Reinhold.

24. Harvey, D. (2007). Neoliberalism as Creative Destruction (on-line). Available at: (http://ann.sagepub.com/cgi/content/abstract/610/1/21).

25. Hassan, S. (2000). Determinants of market competitiveness in an environmentally sustainable tourism industry. Journal of Travel Research, 3.

26. Haugland, S. A.; Ness, H.; Gronseth, B. O.; Aarstad, J. (2011). Development of Tourism Destinations: An integrated Multilevel Perspective. Annals of Tourism Research, 38 (1): 268-290.

27. Heath, E. (2003). Towards a model to enhance destination competitiveness: a South African perspecitve. Journal of Hospitality and Tourism Management, 10 (2): 124-141.

28. Hosany, S.; Ekinci, Y. and Uysal, M. (2007). Destination image and destination personality. International Journal of Culture, Tourism and Hospitality Research, 1 (1): 62-81.

29. Hose. T. A. and Wichens, E. (2004). Typologies, tourism locations and images: Meeting the real needs of real tourists, in: Weber, S. and Tomljenovic, R. (Eds.). Reinventing a tourism destination: facing the challenge. Zagreb: Institute for Tourism, 103-114.

30. Hunt, J. D. (1975). Image as a foctor in tourism development. Journal of Travel Research, 13 (3): 1-17.

31. Keller, K. L. (2008). Strategic brand management: Building, measuring and managing brand equity ( $3^{\text {rd }}$ ed.) New Jersey: Prentice Hall.

32. Kunst, I. (2008). Heritage rent - underlying theory and Croatian practice. Tourism, 57 (1): 37-53.

33. Kunst, I. (2009). Tourism destination competitiveness assessment - approach and limitations. Acta turistica, 21 (2): 129-159.

34. Lamsdon, L. M., P. McGrath (2011). Developing a conceptual framework for slow travel: grounded theory approach. Journal of Sustainable Tourism, 19 (3): 265-279.

35. Lawson, F. and Baud-Bovery, M. (1977). Tourism and recreation development. London: Architectural Press.

36. MacKay, K. J. and Fesenmaier, D. R. (1997). Pictorial element of destination in image formation. Annals of Tourism Research, 24 (3): 537-565.

37. Marušić, Z.; Čorak, S. and Sever, I. (2015). TOMAS ljeto 2014 - Stavovi i potrošnja turista u Hrvatskoj: Obilježja turističke potražnje u Dubrovačko-neretvanskoj županiji.

38. McKercher, B. (2001). Attitudes to a Non-Viable Community-Owned Heritage Tourist Attraction. Journal of Sustainable Tourism, 9: 29-43.

39. McLennan, C.J., B.W. Ritchie, L.M. Ruhanen, B.D. Moyle (2014) An institutional assessment of three local government-level tourism destinations at different stages of the transformation process. Tourism Management 41, 107-118 
40. Miles, M. B. and Hubarman, A. M. (1984). Qualitative data analysis. Newbury Park: Sage.

41. Milman, A. and Pizan, A. (1995). Thr Role of the Awareness and Familiarity with a Destination: The Central Florida Case. Journal of Travel Research, 33: 21-27.

42. Mišetić, A. i Miletić, G. M. (2014). Provedba participationog procesa na pilot području Dubrovnika - istraživačko izvješce. Zagreb: Institut Ivo Pilar.

43. Morgan, N.; Pritchard, A. and Pride, R. (2004). Destination branding: Creating the unique destination proposition. Oxford: Elsevier Butterworht-Heinemann.

44. Morisson, A. M. (2013). Marketing and managing tourist destinations. New York: Routledge.

45. Palmer, C. (1999). Tourism and the Symbols of Identity. Tourism Management, 20: 313-321.

46. Pike, S. (2002). Destination image analysis - a review of 142 papers from 1973 to 2000. Tourism Management, 23 (5): 541-549.

47. Pine, J. B. and Gilmore, J. H. (1998). Welcome to the experience economy. Harvard Business Review, July-August.

48. Pine, J. D. and Gilmore, J. H. (1999). The experience economy. Boston: Harvard Business School Press.

49. Porter, M. (1980). Competitive strategy: techniques for analysing industries and competitors. New York: The Free Press.

50. Reid, D. G.; Mair, H. and George, W. (2004). Community tourism planning: a self-assessment instrument. Annals of Tourism Research, 31 (3): 623-639.

51. Richards, G. (2007). Introduction: Global Trends in Cultural Tourism, in: Richards, G. (Ed.). Cultural Tourism - Global and Local Perspective. Binghamton, NY: The Haworth Hospitality Press.

52. Ritchie, J. R. B. and Crouch, G. (1999). Tourism, Competitiveness, and Societal Prosperity. Journal of Business Research, 44 (3): 137-152.

53. Ritchie, B. J. R. and Crouch, G. L. (2003). The competitive destination. Cambridge: CAB International.

54. Simpson, K. (2001). Strategic planning and community involvement as contributors to sustainable tourism development. Current Issues in Tourism, 4 (1): 3-41.

55. Stepchankova, S. and Morrison, A. M. (2006). The destination image of Russia: from the online induced perspective. Tourism management, 27: 943-956.

56. Stylianou-Lambert, T. (2011). Gazing from home: cultural tourism and art museums. Annals of Tourism Research, 38 (2): 403-421.

57. Tasci, A. D. and Gartner, W. C. (2007). Destination image and its functional relationships. Journal of Travel Research, 4 (2): 186-196.

58. Taylor, J. (2001). Authenticity and Sincerity in Tourism. Annals of Tourism Research, 28 (1): 7-26.

59. Telišman Košuta, N. (1994). Tourist destination image, in: Witt, S. and Moutinho, L. (Eds). Tourism marketing and management handbook. Cambridge: Prentice Hall, 557-561.

60. Tomljenović, R. and Kunst, I. (2014). From sun and sea tourism to cultural tourism - the case of Split-Dalmatia county. European Journal of Tourism Research, 8: 83-98.

61. Trauer, B. (2006). Conceptualizing special interest tourism - frameworks for analysis. Tourism Management, 27 (2): 183-200. 
62. TZ grada Dubrovnika (2013). Anketa o zadovoljstvu gostiju turističkom ponudom Grada Dubrovnika.

63. UNWTO (2016). Tourism Highlights.

64. Urry J. (2001). The tourist gaze ( $2^{\text {nd }}$ ed). London: Sage.

65. Urry, J. and Larsen, J. (2012). The Tourist Gaze 3.0. London: Sage.

66. Van der Helm, R. (2009). The vision phenomenon: towards a theoretical underpinning of visions of the future and the process of envisioning. Futures, 41: 96-104.

67. Wehrmeyer, W.; Clayton, A. and Lum, K. (2002). Foresighting for development. Greener Management International, 37: 24-37.

68. World Tourism Organization (1979). Tourist Images. Madrid. 
Pregledni rad

Ivo Kunst

Institut za turizam, Zagreb, Hrvatska

e-mail:ivo.kunst@iztzg.hr

Redizajn imidža kao jamstvo osiguranja tržišnog uspjeha destinacije: slučaj Dubrovnika

\section{Sažetak}

Grad Dubrovnik, osobito njegova povijesna jezgra pod zaštitom UNESCO-a, kao i prostor u njegovoj neposrednoj blizini izloženi su prekomjernoj turističkoj potražnji već dulje od desetljeća. To posebno vrijedi za tzv. tranzitne turiste, koji grad posjećuju s kruzera ili u okviru organiziranih turističkih grupa. Slijedom toga povijesna je jezgra sve zakrčenija turistima. To je praćeno opadanjem kvalitete ponude hrane i pića kao i ostalih usluga jer se svi prilagođuju takvom, manje zahtjevnom tranzitnom turizmu. Sve navedeno ne samo da ozbiljno ugrožava kvalitetu života stanovnika grada već ima i važne implikacije za dugoročni imidž Dubrovnika kao turističke destinacije na svjetskom tržištu. Nakon kritičkog ispitivanja trenutne politike razvoja turizma i njezine održivosti, kako u socioekonomskom kontekstu tako i u kontekstu dugoročnog utjecaja na tržišno pozicioniranje grada, na temelju nalaza provedenog kvalitativnog istraživanja u radu se predlažu promjene u jedinstvenoj prodajnoj ponudi Grada. One imaju za cilj smanjiti problem zakrčenosti turistima i održati konkurentnost Dubrovnika na tržištu turističkih destinacija u godinama koje dolaze.

Ključne riječi: Dubrovnik, model razvoja turizma, tržišni uspjeh, održivost. 